Gut, 1974, 15, 220-226

\title{
Sites of competition in the selective hepatic uptake of rifamycin-SV, flavaspidic acid, bilirubin, and bromsulphthalein
}

\author{
S. KENWRIGHT AND A. J. LEVI
}

From the Clinical Research Centre, Watford Road, Harrow, Middlesex

SUMMARY In rats both rifamycin-SV and flavaspidic acid impaired the disappearance of bromsulphthalein (BSP) from plasma. The addition of rifamycin-SV to rat liver supernatant containing BSP did not displace BSP from ligandin or $\mathrm{Z}$ protein unless it was added in very high concentration. In similar studies in vitro with flavaspidic acid, BSP was displaced from $Z$ protein even at low concentrations of flavaspidic acid, whereas there was only a minor effect on the binding to ligandin.

The intravenous administration of rifamycin to Gunn rats raised the plasma bilirubin concentration slightly after 30 minutes whereas flavaspidic acid was without significant effect. At 30 minutes the amount of bilirubin in the liver was markedly reduced by rifamycin and moderately depressed by flavaspidic acid. Although both the rifamycin and flavaspidic acid lowered the bilirubin in cell sap, the main effect of flavaspidic acid appeared to be on binding to $Z$ protein. Rifamycin reduced the amount bound to both ligandin and $\mathrm{Z}$ protein. It is suggested that flavaspidic acid acted on the hepatic uptake of bilirubin and BSP predominantly by competing for binding to $\mathrm{Z}$ protein. Rifamycin-SV acted at a different site, probably blocking uptake at the plasma membrane.

The mechanisms for the selective hepatic uptake of bilirubin, bromsulpt.thalein (BSP) and a number of other drugs are poorly understood. There is evidence that the cytoplasmic acceptor proteins, ligandin (formerly called $\mathrm{Y}$ ) and $\mathrm{Z}$, have an important role in the uptake process, but their exact physiological function is not yet clear.

Present evidence suggests that bilirubin and BSP cross the plasma membrane by facilitated or nonionic diffusion. Rapid bidirectional fluxes across the membrane can occur (Goresky, 1965). Cornelius, Ben Ezzer, and Arias (1967) showed that a number of drugs compete for binding to isolated liver cell membranes in vitro. Within the liver cell, ligandin and $\mathrm{Z}$ proteins have been shown to bind numerous compounds. These include bilirubin, BSP, indocyanine green (ICG), several fatty acids, and metabolites of cortisol and a number of drugs and azodye carcinogens (Ketterer, Ross-Mansell, and Whitehead, 1967; Levi, Gatmaitan, and Arias, 1969; Morey and Litwack, 1969; Mishkin, Stein, Gatmaitan, and Arias, 1972). High affinity binding sites on ligandin and $Z$ protein could provide one mechanism for the selective hepatic uptake of these compounds Received for publication 16 January 1974. and a possible site for competition. Alternatively, binding to these cytoplasmic proteins might be relatively non-specific, with some selectivity and competition taking place primarily at the level of the plasma membrane.

Rifamycin antibiotics (Cohn, 1969; Capelle, Dhumeaux, Mora, Feldmann, and Berthelot, 1972) and flavaspidic acid (Nosslin, 1963; Nosslin and Morgan, 1965; Hammaker and Schmid, 1967) can each cause a rise in the serum unconjugated bilirubin in man and other animals, probably due to impaired hepatic uptake. The present study was undertaken to determine whether competition for binding sites on ligandin or $\mathrm{Z}$ protein is the mechanism of this unconjugated hyperbilirubinaemia, and to assess whether competitive hepatic uptake studies would clarify the role of the plasma membrane and the cytoplasmic acceptor proteins in the hepatic uptake process.

\section{Methods}

In principle, the effect of rifamycin-SV and flavaspidic acid on the hepatic uptake of BSP was measured in rats in vivo and compared with the ability of the 
drugs to displace BSP from ligandin and $\mathrm{Z}$ protein in vitro. The effects of the drugs on the distribution of bilirubin in the liver cell and its subfractions in rats with congenital unconjugated hyperbilirubinaemia was also investigated.

Male Sprague-Dawley rats (body weight 325-450g) or homozygous Gunn rats (body weight 355-495g) were used. Gunn rats are congenitally jaundiced, due to a deficiency of glucuronyl transferase. Animals were fed ad libitum Spillers' laboratory no. 1 diet.

The following preparations were used: BSP solution, $50 \mathrm{mg} / \mathrm{ml}$ (Hynson, Westcott, and Dunning, Inc, USA); rifamycin-SV, $25 \mathrm{mg} / \mathrm{ml}$ (Rifocin, Lepetit); and flavaspidic acid-N-methylglucaminate (Dr Esa Aho, Turku, Finland) dissolved in water for injection BP as necessary. In the experiments in vivo, all compounds were injected into the penile vein in a volume of $0.1 \mathrm{ml} / 100 \mathrm{~g}$ body weight.

Bilirubin was estimated in serum by the technique of Michaëlsson, Nosslin, and Sjöhn (1965) or by the method of Van Roy, Meuwissen, De Meuter, and Heirwegh (1971), modified by the addition of the anti-oxidant 2,6-di-tert-butyl-p-cresol (Mertens, Van de Vijver, and Heirwegh, 1972). The latter method was also used for bilirubin estimations in liver homogenate, supernatant, and protein fractions. Both techniques gave similar serum values and neither rifamycin-SV nor flavaspidic acid interfered with the estimations.

Rifamycin concentrations in rat liver supernatant were measured by a modification of the spectrophotometric assay of Păunescu and Stoinescu (1969).

THE EFFECT OF THE DRUGS ON THE PLASMA CLEARANCE OF BSP

The initial plasma disappearance rate of BSP was measured as previously described (Reyes, Levi, Gatmaitan, and Arias, 1969). Blood samples were taken from a sliced tail vein every 30 seconds between two and eight minutes after the intravenous injection of BSP, $6 \mu \mathrm{mol} / 100 \mathrm{~g}$ body weight. The concentrations of BSP were plotted on semilogarithmic paper against time. The best fit line was drawn for determination of the $t \frac{1}{2}$ and the initial plasma disappearance rate, $K_{1}$, calculated $\left(K_{1}=\frac{2 \ln }{t_{\frac{1}{2}}}\right)$. The BSP $\mathrm{K}_{1}$ was determined after the injection of BSP alone and also in the following groups of animals in which BSP was injected at various times after the injection of saline or test drug: (1) five minutes after saline; (2) 10, 30, and 60 minutes after rifamycin-SV $3.6 \mu \mathrm{mol} / 100 \mathrm{~g}$ body weight; (3) at similar times after flavaspidic acid $5 \mu \mathrm{mol} / 100 \mathrm{~g}$ body weight.

The drugs did not interfere with BSP estimation.
EFFECT OF DRUGS in vitro ON BSP BINDING BY PROTEIN FRACTIONS

Bromsulphthalein bound to the ligandin and $Z$ protein fractions was measured by triangulation of the area under the respective peaks following Sephadex G-75 gel filtration at $4^{\circ} \mathrm{C}$ of the $100000 \times$ $\mathrm{g}$ rat liver supernatant (Levi et al, 1969). Bromsulphthalein and saline or the test drug were added in vitro. A typical result is shown in figure 1. Com-

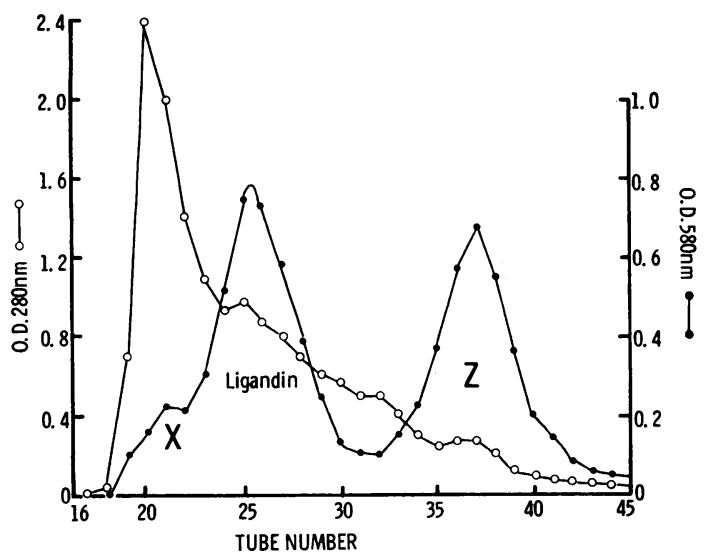

Fig $1 X$, ligandin, and $Z$ protein fractions following Sephadex G-75 gel filtration of supernatant from $1 \mathrm{~g}$ of liver with $B S P(1 \cdot 2 \mu \mathrm{mol})$ added in vitro ${ }^{1}$

${ }^{1}$ Column size $39 \times 2.5 \mathrm{~cm}$, flow rate $3.4 \mathrm{ml} /$ tube $/ 9 \mathrm{~min}$ OD $280 \mathrm{~nm}$ indicates protein, OD $580 \mathrm{~nm}$ indicates BSP (after alkalinization).

parable columns were used $2.5 \times 40( \pm 1) \mathrm{cm}$, flow rate $3.2( \pm 0.3) \mathrm{ml} / 9$ minutes. The aliquots of supernatant were equivalent to $1 \mathrm{~g}$ of liver and were prepared from pooled liver homogenate from Sprague-Dawley rats. These techniques of separation give reproducible results provided that experimental conditions are kept constant. The SE of the mean value of BSP bound to the protein fractions is less than $3 \%$ for ligandin and less than $7.5 \%$ for $\mathrm{Z}$ protein, in any one series of experiments.

STUDIES ON GUNN RATS in vivo

The effect of rifamycin-SV or flavaspidic acid on bilirubin concentration in serum, liver homogenate, and supernatant was studied in Gunn rats. Liver pellet values were calculated as the difference between liver homogenate and supernatant values. The drug doses were the same as those used above. In separate experiments the effect of the drugs on bilirubin bound to $\mathrm{X}$, ligandin, and $\mathrm{Z}$ fractions was investigated using Sephadex G-75 gel filtration. In these experiments the columns, which were protected 
from light, were $2.5 \times 90( \pm 1) \mathrm{cm}$ flow rate 5 $( \pm 0.5) \mathrm{ml} / 9$ minutes. Serum and tissue levels were determined 30 minutes after treatment with saline or test drug. In most studies blood samples were taken from the tail vein initially and from the inferior vena cava at 30 minutes. In a few studies the 30-minute sample was also taken from the tail vein. In studies estimating bilirubin bound to $X$, ligandin, and $\mathrm{Z}$ fractions, Gunn rat supernatant from $4 \mathrm{~g}$ of liver was used. Peaks representing the various fractions were selected by their chromatographic position and yellow colour. Pooled eluates were concentrated in a Diaflo cell before the bilirubin estimations. The time from loading the column to bilirubin estimation was approximately 20 hours.

\section{STUDIES ON GUNN RAT LIVER SUPERNATANT} in vitro

In similar studies rifamycin-SV or saline was added in vitro to aliquots of Gunn rat liver supernatant, and the two samples were run simultaneously. Two dosages of rifamycin-SV were used. The low dose was equivalent to the concentration of rifamycin in the supernatant of Sprague-Dawley rats 30 minutes after the injection of rifamycin-SV 3.6 $\mu \mathrm{mol} / 100 \mathrm{~g}$ body weight. The high dose of rifamycinSV added in vitro was 10 times greater than the low dose. In studies both in vivo and in vitro on bilirubin bound to the $X$, ligandin, and $Z$ fractions, a specimen of supernatant was kept at $4^{\circ} \mathrm{C}$ during the period of separation by gel filtration. The bilirubin content of this specimen was determined at the same time as the concentrations in the protein fractions. This delay in estimation produced a fall of 3 to $8 \%$ in the supernatant bilirubin concentration. Allowing for this loss the mean recovery of bilirubin from the pooled $\mathrm{X}$, ligandin, and $\mathrm{Z}$ protein fractions was $84.1 \%$ (SE \pm 1.8$)$ of the supernatant bilirubin concentration. To allow for a comparison between studies, the bilirubin recoveries in individual experiments were standardized to an $85 \%$ recovery rate. This correction assumes a uniform loss from all fractions.

Standard statistical techniques were used to calculate means, standard errors, and $P$ values.

\section{Results}

BSP STUDIES in vivo AND in vitro

The BSP $\mathrm{K}_{1}$ of control rats was $0.183(\mathrm{SE} \pm 0.005)$ and was not affected significantly by saline nor did it differ in Gunn rats. Each drug significantly depressed the $K_{1}(P<0.001)$ whether given at 10 , 30 , or 60 minutes before the BSP (fig 2). In vitro, rifamycin-SV had little effect on the binding of BSP to ligandin or $Z$. When present in eight-fold

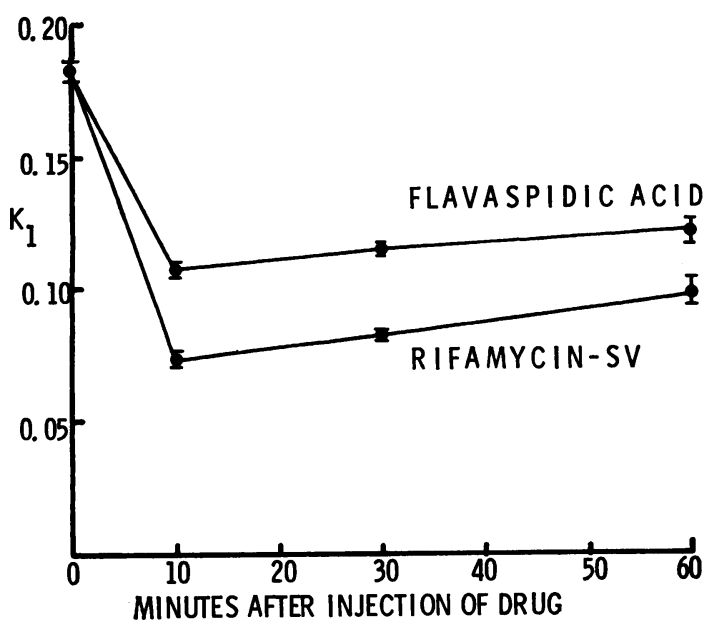

Fig 2 Effect of rifamycin-SV (3.6 $\mu \mathrm{mol} / 100 \mathrm{~g}$ body weight $)$ or flavaspidic acid $(5 \mu \mathrm{mol} / 100 \mathrm{~g}$ body weight) on BSP $K_{1}$ at 10,30 , and 60 minutes after drug. (four rats in each group). ${ }^{1}$

${ }^{1}$ Means \pm SE shown with control values, without drugs, at time zero

molar excess there was only minor displacement from ligandin $(8.1 \%)$ and $Z(8.5 \%)$ (table I). Even greater molar excess was achieved by lowering the BSP concentration, but no further displacement occurred. In contrast to these results, flavaspidic acid, when present in only one tenth of the molar

\begin{tabular}{llll}
\hline $\begin{array}{l}\text { Molar Excess of } \\
\text { Rifamycin-SV }\end{array}$ & No. & Ligandin & $Z$ \\
\hline Control & 7 & $0.271(0.005)$ & $0.088(0.003)$ \\
3.6 & 4 & $0.270(0.008)$ & $0.082(0.006)$ \\
8.0 & 4 & $0.248(0.004)$ & $0.075(0.001)$ \\
\hline
\end{tabular}

Table I Effect of rifamycin-SV on BSP $(4.5 \mu \mathrm{mol})$ binding in vitro ${ }^{1}$

${ }^{1}$ Results expressed as mean $\mu$ moles $\mathrm{BSP} /$ fraction/g equivalent of liver $\pm \mathrm{SE}$ in brackets

concentration of BSP, displaced over half the BSP from $Z$ (fig 3). Higher molar ratios of flavaspidic acid to BSP led to almost complete displacement of the dye from $Z$. Displacement from ligandin only occurred when flavaspidic acid was added in 10-fold molar excess and at low concentrations of flavaspidic acid a slight increase in binding of the dye by ligandin was found $(\mathrm{P}<0.05)$.

\section{BILIRUBIN STUDIES}

\section{Serum values}

The mean pretreatment serum bilirubin concentration was $86 \mu \mathrm{g} / \mathrm{ml}$ and was similar in the various 


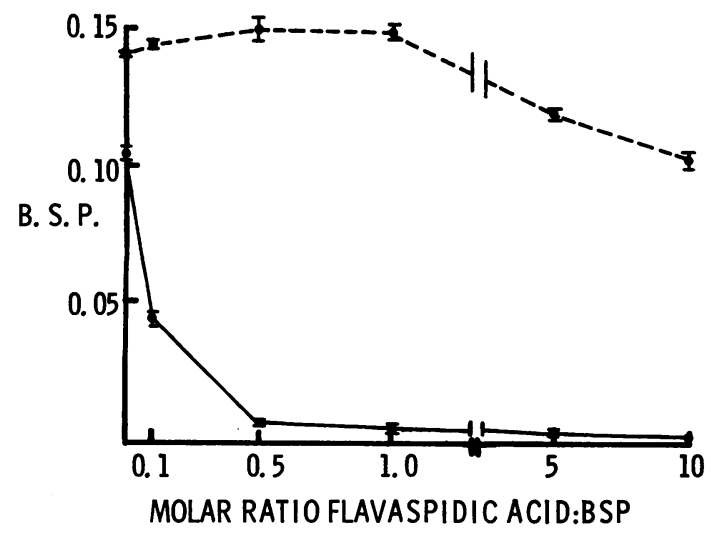

Fig 3 Displacement of BSP (1.2 $\mu$ moles) from ligandin (- - - - - ) and $Z$ protein (- $\longrightarrow$ by flavaspidic acid, BSP in $\mu \mathrm{mol} /$ fraction/1 $\mathrm{g}$ equivalent of liver; four to eight rats in each group. Results expressed as means $\pm S E$.

groups. Changes in concentration seemed to depend on the site from which blood was taken. All pretreatment samples were taken from a tail vein. When the second sample was also taken from a tail vein, no significant difference was found in salinetreated animals, but when the second sample was taken from the inferior vena cava (IVC) there was a small, but significant, fall, $6.6 \mu \mathrm{g} / \mathrm{ml}(\mathrm{P}<0.001)$. With blood from the inferior vena cava, the mean fall after flavaspidic acid, $5 \mu \mathrm{g} / \mathrm{ml}$, was not significantly different from the mean fall following saline $(P>0 \cdot 3)$. Rifamycin-SV produced mean rises in serum bilirubin of $3.1 \mu \mathrm{g} / \mathrm{ml}$ when the second sample was taken from the inferior vena cava and $13.3 \mu \mathrm{g} / \mathrm{ml}$ in blood from a tail vein. These mean differences were significantly higher than in the saline-treated controls, $P<0.01$ (inferior vena cava) and 0.025 (tail vein).

\section{Tissue values}

Thirty minutes after the injection of rifamycin-SV, the liver bilirubin concentration was $39 \%$ of the control value and after flavaspidic acid, $79 \%$ $(P<0.01)$ (table II). Although after rifamycin-SV the liver fractions all showed similar percentage decreases $(P<0.01)$, after flavaspidic acid the bilirubin content of the supernatant fell to $57 \%$ (P <
$0.01)$ while the content of the pellet rose to $137 \%$ $(P<0 \cdot 1)$ (table II).

In a separate group of experiments changes in the bilirubin concentrations of the supernatant, $X$, ligandin and $\mathrm{Z}$ protein fractions were studied (fig 4). Rifamycin-SV reduced bilirubin in the super-

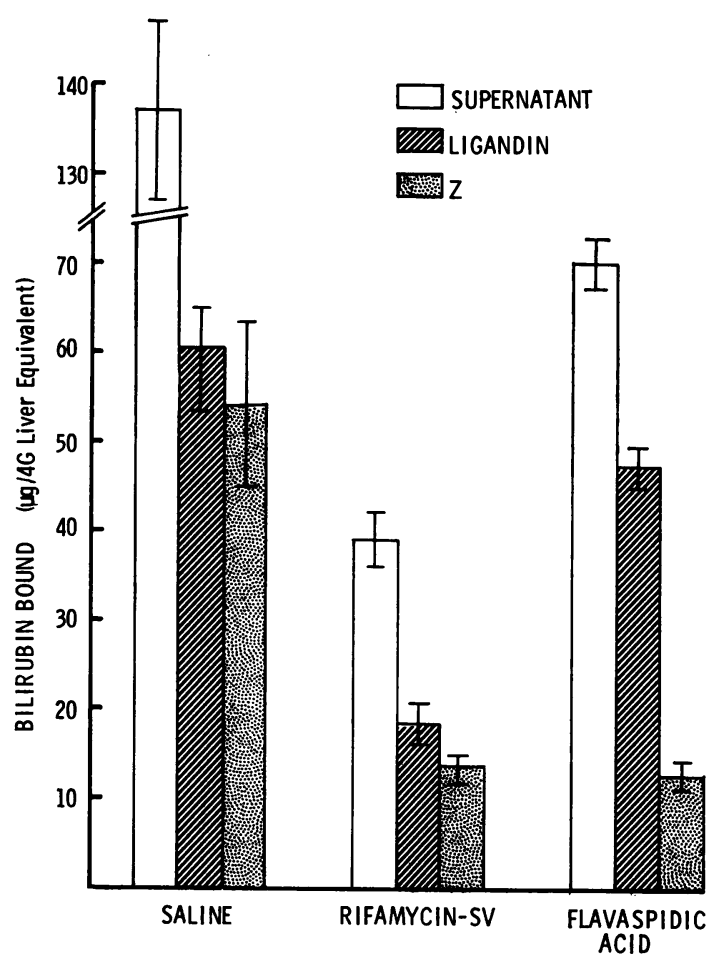

Fig 4 Effects of drugs on bilirubin bound by supernatant (open), ligandin (hatched), $Z$ (stippled) fractions ${ }^{1}$

${ }^{1}$ Five to six rats in each group; mean values $\pm S E$.

natant to $28 \%$ of control values and that bound to ligandin and $\mathrm{Z}$ fractions in similar proportions, ie, to 30 and $24 \%$ respectively. Flavaspidic acid, however, predominantly displaced bilirubin from $\mathrm{Z}$, with a mean fall to $22 \%$ of control values. Bilirubin concentration in the ligandin fraction only fell to $74 \%(\mathrm{P}<0.01)$ with an overall reduction in the supernatant to $51 \%$ (fig 4). Thus, rifamycin-SV reduced total liver, supernatant, pellet, ligandin, and $\mathrm{Z}$ bilirubin levels in approximately equal propor-

\begin{tabular}{|c|c|c|c|c|}
\hline Drug & No. & Homogenate & Supernatant & Pellet \\
\hline $\begin{array}{l}\text { Saline } \\
\text { Rifamycin-SV } \\
\text { Flavaspidic acid }\end{array}$ & $\begin{array}{l}5 \\
6 \\
4\end{array}$ & $\begin{array}{l}45.5(2.2)^{1} \\
17.6(0.9) \\
35.8(1 \cdot 2)\end{array}$ & $\begin{array}{l}32.9(1.6) \\
11.8(0.7) \\
18.6(1.2)\end{array}$ & $\begin{array}{r}12.6(1.9) \\
5.8(0.7) \\
17.2(0.5)\end{array}$ \\
\hline
\end{tabular}

Table II Bilirubin concentrations ( $\mu \mathrm{g} / \mathrm{g}$ liver equivalent) in liver homogenate, supernatant, and pellet 30 minutes after test injection

Mean value $\pm S E$

3 
tions, whilst raising the serum concentration when compared with saline-treated controls. In contrast, flavaspidic acid predominantly displaced bilirubin from $\mathrm{Z}$ and increased pellet values. The concentration of bilirubin bound to the $\mathrm{X}$ fraction was similar in all studies.

Studies in vitro were carried out to determine whether the addition of rifamycin-SV to Gunn rat liver supernatant could produce selective displacement of bilirubin from ligandin or Z. At supernatant concentrations of rifamycin-SV comparable to those found in the experiments in vivo, bilirubin bound to $\mathrm{Z}$ was reduced to $80 \%(\mathrm{P}<0.005)$ with slight increases in $X(P>0.2)$ and ligandin (to $113 \%, P<0.005)$ compared with control values. In these experiments rifamycin-SV was present at more than twice the molar concentration of bilirubin. Even at a 10-fold greater concentration, rifamycinSV only reduced the bilirubin bound to ligandin to $81 \%(P<0.05)$, whilst that bound to $\mathrm{Z}$ was reduced to less than one third of the control value (fig 5). The

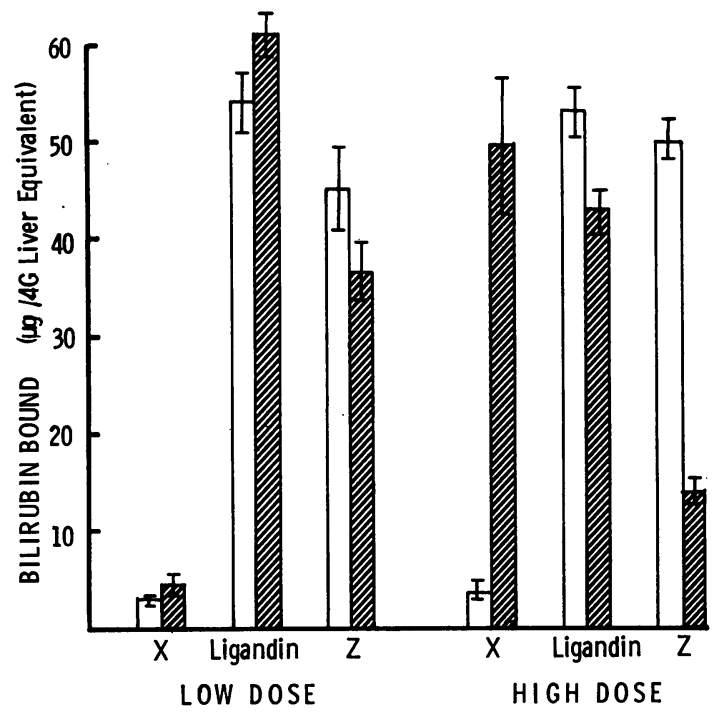

IN VITRO

Fig 5 Effect in vitro of rifamycin-SV (hatched) at two doses on bilirubin bound by $X$, ligandin, and $Z$ fractions compared with saline controls (open) ${ }^{1}$

${ }^{1}$ Four rats in each group; mean values \pm SE. bilirubin displaced from ligandin and $\mathrm{Z}$ at the high dosage was recovered from the $X$ fraction. Thus a completely different pattern of bilirubin binding is found when rifamycin-SV is added in vitro compared with the studies in vivo.

\section{Discussion}

The hepatic uptake of bilirubin and BSP is a poorly understood, complex process. There appear to be at least three stages: (1) preliminary dissociation from plasma albumin, (2) transfer by non-ionic or facilitated diffusion across the liver cell membrane, and (3) intracellular binding by ligandin and/or $\mathrm{Z}$ proteins (Bloomer, Berk, Vergalla, and Berlin, 1973; Levi et al, 1969; Fleischner and Arias, 1970). The results of the present studies are summarized in tables III and IV. They suggest that flavaspidic acid predominantly affects bilirubin uptake by competition for binding to $\mathrm{Z}$ protein, but that rifamycin$\mathrm{SV}$ is competing at an earlier step, perhaps at the plasma membrane. Thus, evidence is provided for at least two sites of competition in the hepatic uptake process.

The rifamycin antibiotics in clinical use are selectively taken up by the liver and excreted in high concentration in the bile. Serum bilirubin levels often rise following treatment and several mechanisms seem to be involved (Acocella and Billing, 1965; Acocella, Nicolis, and Tenconi, 1965; Cohn, 1969; Lees, Allan, Smith, Tyrrell, and Fallon, 1971; Capelle et al, 1972). A transient rise in the serum unconjugated bilirubin seems to be particularly common, although this effect usually disappears during the first two weeks of treatment. This rise is apparently caused by impaired hepatic uptake and not by increased red cell destruction or hepatotoxicity (Cohn, 1969). The rifamycins also depress the fractional clearance of ICG and BSP (Acocella et al, 1965; Paumgartner, Probst, Kraine, and Leevy, 1970; Capelle et al, 1972), compounds which have different metabolic pathways within the liver cell.

In the present studies, rifamycin-SV caused a gross impairment of BSP uptake in vivo but did not displace BSP from ligandin or $\mathrm{Z}$ in vitro (table IV). This suggests that the uptake defect is unlikely to be caused by competition for binding to these proteins. In the bilirubin studies in vivo, rifamycin-SV

\begin{tabular}{|c|c|c|c|c|c|c|}
\hline & Serum & Homogenate & Supernatant & Pellet & Ligandin & $Z$ \\
\hline $\begin{array}{l}\text { Rifamycin-SV } \\
\text { Flavaspidic acid }\end{array}$ & $\stackrel{\uparrow}{\text { N.C. }}$ & $\downarrow \downarrow \downarrow$ & $\begin{array}{l}\downarrow \downarrow \downarrow \\
\downarrow \downarrow\end{array}$ & $\downarrow \downarrow$ & $\downarrow \downarrow \downarrow$ & $\begin{array}{l}\downarrow \downarrow \\
\downarrow \downarrow\end{array}$ \\
\hline
\end{tabular}

Table III Summary of effects in vivo of drugs compared with saline controls on bilirubin concentrations in serum and liver homogenate, supernatant, and $Z$ fractions

$\mathrm{NC}=$ no change 


\begin{tabular}{llll}
\hline & $B S P K_{1}$ & Ligandin & $Z$ \\
\hline Rifamycin-SV & $\downarrow$ & - & - \\
Flavaspidic acid & $\downarrow$ & - & $\downarrow$ \\
\hline
\end{tabular}

Table IV Summary of effects of drugs on BSP $K_{1}$ and on displacement in vitro of BSP from ligandin and $Z$ fractions

produced a rise in serum bilirubin concentration with a marked fall in liver homogenate, supernatant, and pellet, as well as ligandin and $Z$, values. This fall was not selective, with a similar percentage fall occurring from all fractions (table III). These results suggest that rifamycin-SV might be blocking the uptake of bilirubin and BSP at the level of the plasma membrane and preventing them from entering the liver cell. This view is supported by the completely different pattern of displacement of bilirubin which was found when rifamycin-SV was added in vitro to Gunn supernatant and produced selective displacement from $\mathbf{Z}$ protein. Although rifamycin antibiotics do not seem to compete with bilirubin for binding to albumin (Cohn; 1969), the possibility that rifamycin-SV causes a change in the conformation of the albumin-bilirubin complex has not been explored in this study. Such a change could affect the binding of bilirubin to albumin or the dissociation of the complex at the plasma membrane. This does not seem to be a probable mechanism as the reductions in bilirubin in the liver cell and its fractions suggest that efflux of bilirubin from the liver cell is relatively unimpaired.

Levi et al (1969) suggested that flavaspidic acid, the main chemical responsible for the unconjugated hyperbilirubinaemia following administration of male fern extract (Nosslin and Morgan, 1965), may interfere with the uptake of bilirubin by competing for binding to $\mathrm{Z}$ protein. The results here strongly suggest that this is the predominant mechanism. In vivo, total liver bilirubin concentrations were reduced by flavaspidic acid and this reduction was largely accounted for by displacement from $Z$ protein, with increased amounts of bilirubin being found in the liver pellet (table III). The displacement in vitro of BSP from $\mathrm{Z}$ protein by very low concentrations of flavaspidic acid suggests that competition for binding to this protein is also the main mechanism of the impaired hepatic uptake of BSP found in vivo (table IV). The possibility of some interaction occurring at the liver cell membrane, as suggested by Cornelius et al (1967), working with isolated cell membranes, has not been excluded, but is not a necessary hypothesis to explain these findings, and cannot be the main site of interaction. There was no rise in serum bilirubin levels, with respect to controls, after flavaspidic acid, and this had been previously $3^{*}$ found by Hammaker and Schmid (1967). However, the total displacement of bilirubin from the liver was less than after rifamycin-SV even though the flavaspidic acid was given at a relatively higher dose. The analysis of the mechanisms involved in hepatic uptake has been hindered by the complexity and rapidity of the processes involved, and by the technical difficulties of differentiating uptake from other variables. In this study, the initial plasma clearance of BSP was used as the measure of BSP uptake by the liver, and alterations in the tissue distribution of bilirubin in Gunn rats as the measure of net bilirubin uptake.

The physiological role of the acceptor proteins, ligandin and $\mathbf{Z}$, has not been fully explored, but there is evidence that they are important in facilitating the selective hepatic uptake of bilirubin and BSP (Levi et al, 1969; Levi, Gatmaitain, and Arias, 1970). Studies on plasma clearance, hepatic transport maxima and storage, multicompartmental analyses, and complex flow techniques have all been used to investigate the problem of hepatic uptake, but without elucidating the role of the plasma membrane or the acceptor proteins and without explaining the mechanism of the hepatic uptake defect produced by a number of drugs. In mutant Southdown sheep there is a hepatic uptake defect for various organic anions (Cornelius and Gronwall, 1968). Preliminary evidence suggests that there is no major quantitative difference in the acceptor proteins in mutant sheep compared with normal sheep (Levi et al, 1969) and in these mutants there might be a defect at the level of the plasma membrane (Mia, Gronwall, and Cornelius, 1970). This could provide further evidence of the importance of the membrane as a site for hepatic selectivity. In man, Berk, Blaschke, and Waggoner (1972) found no close correlation between the hepatic uptake defects for bilirubin, BSP, and indocyanine green in patients with Gilberts' syndrome. This could be additional evidence for different sites of hepatic selectivity.

The present study suggests that competitive uptake studies can be used to clarify the mechanisms of hepatic selectivity. The results also help to elucidate the mechanism of the unconjugated hyperbilirubinaemia found following rifamycin antibiotics. It is suggested that competition with bilirubin might be occurring at the level of the plasma membrane. Flavaspidic acid apparently acts at a different site, largely by competing for binding to $\mathrm{Z}$ protein. The study also demonstrates the need for experiments both in vivo and in vitro in assessing the importance of the acceptor proteins.

We wish to thank Dr Billing of the Royal Free 
Hospital, London, for kindly providing the Gunn rats, and Dr Esa Aho of Turku, Finland and Gruppo Lepetit, Milan, for generously giving us the flavaspidic acid and rifamycin-SV respectively.

S.K. holds a clinical research fellowship from the Medical Research Council.

\section{References}

Acocella, G., and Billing, B. H. (1965). The effect of rifamycin SV on bile pigment excretion in rats. Gastroenterology, 49, 526-530.

Acocella, G., Nicolis, F. B., and Tenconi, L. T. (1965). The effect of an intravenous infusion of rifamycin SV on the excretion of bilirubin. bromsulphalein, and indocyanine green in man. Gastroenterology, 49, 521-525.

Berk, P. D., Blaschke, T. F., and Waggoner, J. G. (1972). Defective bromosulfophthalein clearance in patients with constitutional hepatic dysfunction (Gilbert's syndrome). Gastroenterology, $63,472-481$.

Bloomer, J. R., Berk, P. D., Vergalla, J., and Berlin, N. I. (1973). Influence of albumin on the hepatic uptake of unconjugated bilirubin. Clin. Sci., 45, 505-516.

Capelle, P., Dhumeaux, D., Mora, M., Feldmann, G., and Berthelot, P. (1972). Effect of rifampicin on liver function in man. Gut, 13, 366-371.

Cohn, H. D. (1969). Clinical studies with a new rifamycin derivative. J. clin. Pharmacol., 9, 118-125.

Cornelius, C. E., Ben-Ezzer, J., and Arias, I. M. (1967). Binding of sulfobromophthalein sodium (BSP) and other organic anions by isolated hepatic cell plasma membranes in vitro. Proc. Soc. exp. Biol. (N.Y.), 124, 665-667.

Cornelius, C. E., and Gronwall, R. R. (1968). Congenital photosensitivity and hyperbilirubinemia in Southdown sheep in the United States. Amer. J. vet. Res., 29, 291-295.

Fleischner, G., and Arias, I. M. (1970). Recent advances in bilirubin formation, transport, metabolism and excretion. Amer. $J$. Med., 49, 576-589.

Goresky, C. A. (1965). The hepatic uptake and excretion of sulfobromophthalein and bilirubin. Canad. med. Ass. J., 92, 851-857.

Hammaker, L., and Schmid, R. (1967). Interference with bile pigment uptake in the liver by flavaspidic acid. Gastroenterology, 53, 31-37.

Ketterer, B., Ross-Mansell, P., and Whitehead, J. K. (1967). The isolation of carcinogen binding protein from livers of rats given 4 dimethylaminoazobenzene. Biochem. J., 103, 316-324.
Lees, A. W., Allan, G. W., Smith, J., Tyrrell, W. F., and Fallon, R. J. (1971). Toxicity from rifampicin plus isoniazid and rifampicin plus ethambutol therapy. Tubercle, 52, 182-190.

Levi, A. J., Gatmaitan, Z., and Arias, I. M. (1969). Two hepatic cytoplasmic protein fractions, $\mathbf{Y}$ and $\mathbf{Z}$, and their possible role in the hepatic uptake of bilirubin, sulfobromophthalein, and other anions. J. clin. Invest., 48, 2156-2167.

Levi, A. J., Gatmaitan, Z., and Arias, I. M. (1970). Deficiency of hepatic organic anion-binding protein, impaired organic anion uptake by liver land 'physiologic' jaundice in newborn monkeys. New Engl. J. Med., 283, 1136-1139.

Mertens, B. B. E., Van de Vijver, N., and Heirwegh, K. (1972). Determination of bilirubin in liver homogenate. Analyt. Biochem., 50, 652-655.

Mia, A. S., Gronwall, R. R., and Cornelius, C. E. (1970). Bilirubin${ }^{14} \mathrm{C} t$ drnover studies in normal and mutant Southdown sheep with congenital hyperbilirubinemia. Proc. Soc. Exp. Biol. (N.Y.), 133, 955-959.

Michaëlsson, M., Nosslin, B., and Sjölin, S. (1965). Plasma bilirubin determination in the newborn infant. Pediatrics, 35, 925-931.

Mishkin, S., Stein, L., Gatmaitan, Z., and Arias, I. M. (1972). The binding of fatty acids to cytoplasmic proteins: binding to $\mathrm{Z}$ protein in liver and other tissues of the rat. Biochem. biophys. Res. Commun., 47, 997-1003.

Morey, K. S., and Litwack, G. (1969). Isolation and properties of cortisol metabolite binding proteins of rat liver cytosol. Biochemistry, 8, 4813-4821.

Nosslin, B. (1963). Bromsulphalein retention and jaundice due to unconjugated bilirubin following treatment with male fern extract. Scand. J. clin. Lab. Invest., 15, Suppl. 69, 206-212.

Nosslin, B., and Morgan, E. H. (1965). The effect of phloroglucinol derivatives from male fern on dye excretion by the liver in the rabbit and rat. J. Lab. clin. Med., 65, 891-902.

Paumgartner, G., Probst, P., Kraines, R., and Leevy, C. M. (1970). Kinetics of indocyanine green removal from the blood. Ann. N.Y. Acad. Sci., 170, 134-147.

Păunescu, E., and Stoinescu, M. (1969). Spectrophotometric and bacteriologic determination of rifampicine in biological products. (Rumanian). Ftiziologia, 18, 467-470.

Reyes, H., Levi, A. J., Gatmaitan, Z., and Arias, I. M. (1969). Organic anion-binding protein in rat liver: drug induction and its physiologic consequence. Proc. nat. Acad. Sci. (Wash.), 64, 168-170.

Van Roy, F. P., Meuwissen, J. A. T. P., De Meuter, F., and Heirwegh, K. P. M. (1971). Determination of bilirubin in liver homogenates and serum with diazotized p-iodoaniline. Clin. chim. Acta, 31, 109-118. 